Article

\title{
From Contractual Flexibility to Contractor's Cooperative Behavior in Construction Projects: The Multiple Mediation Effects of Ongoing Trust and Justice Perception
}

\author{
Haoyang Song *D, Jianhua Hou and Shiqi Tang \\ School of Information Management, Sun Yat-sen University, Guangzhou 510275, China; \\ houjh5@mail.sysu.edu.cn (J.H.); tangshq7@mail2.sysu.edu.cn (S.T.) \\ * Correspondence: songhy29@mail.sysu.edu.cn
}

Citation: Song, H.; Hou, J.; Tang, S. From Contractual Flexibility to

Contractor's Cooperative Behavior in Construction Projects: The Multiple Mediation Effects of Ongoing Trust and Justice Perception. Sustainability 2021, 13, 13654. https://doi.org/ $10.3390 /$ su132413654

Academic Editor: Ermanno C. Tortia

Received: 5 November 2021

Accepted: 8 December 2021

Published: 10 December 2021

Publisher's Note: MDPI stays neutral with regard to jurisdictional claims in published maps and institutional affiliations.

Copyright: (C) 2021 by the authors. Licensee MDPI, Basel, Switzerland. This article is an open access article distributed under the terms and conditions of the Creative Commons Attribution (CC BY) license (https:// creativecommons.org/licenses/by/ $4.0 /)$.

\begin{abstract}
The flexible contract is an important mechanism for owners to govern contractors in construction projects. Given the limited explanatory power of the justice mechanism and the important role of relational factors, this study explored the role of ongoing trust and justice perception in the relationship between contractual flexibility and the contractor's cooperative behavior and aimed to further reveal the potential influence paths through an empirical analysis. We found the following: (1) apart from justice perception, ongoing trust is another crucial mediation factor in the relationship. (2) Together with the former, ongoing trust plays significantly multiple mediation effects and constitutes the main indirect influence paths, among which the parallel one is strongest and the chain one comes third. (3) Moreover, both factors are more likely to be impacted by contract executing flexibility, compared with contract content flexibility. These findings enrich relational mechanism research and provide some guidance for the owner to build contractual flexibility to govern contractors' behavior.
\end{abstract}

Keywords: contractual flexibility; cooperative behavior; ongoing trust; justice perception

\section{Introduction}

Cooperation between the owner and the contractor forms the foundation of effective construction project outcomes [1]. However, due to the one-off, high complexity, diverse interests and information asymmetry between project parties, as well as asset specificity, cooperative relationships are hard to build and maintain automatically [2]. Under this condition, project contracts become the premise of project parties' cooperation [3]. Considering the inability of rigid contracts to adapt to the changing circumstances [4] and the weak legal institutions and high wasteful litigation [5], the owner inclines to sign a flexible contract to set up afterwards adjustable rules in advance, which can motivate the contractor [6], reduce opportunistic behavior [7], and then achieve greater efficiency [1].

Currently, most literature has explored the positive influence of contractual flexibility and qualitatively revealed its potential justice mechanism. Contractual flexibility not only realizes the reasonable transfer and fair sharing of risk between parties and enhances the fair cooperation [8,9] but also provides a compensation mechanism for project uncertainties, which creates a stable environment for cooperation [10,11]. Furthermore, the previous research of this study's authors has demonstrated that justice perception only plays a partial mediation effect between contractual flexibility and cooperative behavior [12], which means there are other important factors that still need to be studied.

On the other hand, according to the literature, trust has been recognized as one of the most central issues when considering the relationship between organizations [13]. The building of trust can effectively reduce the parties' fear of uncertainty, improve the effectiveness of problem solving [14], further reduce opportunistic behaviors [15] and safeguard cooperative behavior [16]. Meanwhile, trust building is influenced by structural and functional factors [17], i.e., roles and responsibilities which are defined in contract. 
Especially, well-prepared, specified contracts allow for risk reduction and make it easier for relations to survive [18], which can enhance trust [19]. Furthermore, there is also a close relationship between fairness and trust, the former to a certain extent constitutes the foundation of the latter. The trust of one partner to the other usually comes from the perception of fairness in the transaction process. If the contractor believes that the owner's behavior is fair and his own interests can be effectively protected, he will have trust in the owner and think that the owner will not do anything harmful to his own interests. In this case, given the crucial role of trust and its close relationship with contracts and behavior, this study further explored its role. Meanwhile, as the parties in a transaction need to continuously prove their credibility through a series of specific interaction activities to promote the development and stability of long-term relationship, trust, as a subjective evaluation, will also change with the interaction between the two. Therefore, trust is not a result-oriented concept but a process-oriented concept. Thus, this study considered it as a dynamic process, namely, ongoing trust, and tried to reveal its role in the relationship.

Therefore, this study takes ongoing trust as a point of departure and incorporate it into the mediation model of justice perception. The question arises as to what the role of ongoing trust between contractual flexibility and contractor's cooperative behavior is and how it works with justice perception. To fill in this gap, this study aims to explore the multiple mediation effects in the construction project and reveals the potential influence paths.

\section{Theoretical Foundation}

\subsection{Contractual Flexibility}

In line with Song, Zhu, Klakegg and Wang [12], we defined contractual flexibility as the contractor's positive ability for dynamic adaptation and flexible adjustment to respond to project uncertainty economically and quickly, in accordance with the provisions of the contract or within the reserved space during the signing and executing of the contract. The contract is not only the visual and explicit contract agreements but also the whole performing process. Especially in the construction project field, the signed contract does not mean the completion of the contract relationship, but the starting point of contracting [20]. Correspondingly, contractual flexibility not only embodies in the various kinds of terms of parties' game also in the relationship and process, which includes content flexibility $(\mathrm{CF})$ and executing flexibility (EF) [12].

Contract content flexibility refers to the adaptability of formal contract. In this way, the contract is equivalent to the transaction contract or agreement, and contractual flexibility is understood as contract (terms) flexibility. The construction of flexible mechanisms or elements of contract terms is concerned. It firstly reflects a contract's completeness, which aims to cover the future possibilities ahead of time through forecasting all kinds of situations and uncertainties [3], such as "terms floating range" and "terms completeness", which go as far as possible to identify uncertainty factors ahead of time to improve the dynamic adaptability of contracts. Secondly, it reflects the active and passive selection space reserved in the adaptive clauses, such as "ex post clause adjustability", "ex post renegotiation clause" and "engineering change authority". The reservation of such space also includes two aspects: active selection and passive selection. The active one means to temporarily shelve identified uncertainty in order to reduce the signing cost [12]. In this way, when specific conditions or circumstances occur, it allows adjustment, renegotiation and other procedures in the project implementation that are specified in the clause. In contrast, the passive one is to set a framework for cooperation, such as some guiding or open clauses, when the uncertainty cannot be predicted due to insufficient information and other reasons, so as to achieve flexible response to future changes when obtaining more information [21]. At this point, some guiding or vague clauses should be set for further acquisition of more information and data, and a new or supplementary contract can be signed through renegotiation to achieve a flexible response to future changes. 
Contract executing flexibility refers to the ability to use the informal contract to replace the formal one in order to address unforeseeable uncertainties effectively, rapidly and economically [12]. This kind of informal contract may include different informal contractual relationships such as commitment and communication. Contract executing flexibility is based on the attributes of the relationship and the informal contract in the contracting and is often introduced into project contracts with relational methods and capabilities [3]. Actually, it mainly derives from relational contracts, an informal agreement formed by the value of future contractual relationships. Generally, it mainly turns to two forms, namely, the usage of informal contracts and flexible authorization [12,21]. The usage of informal contract handles unexpected events in a more flexible way, instead of sticking to inapplicable clauses or complex and time-consuming renegotiation process. Through informal authorizing, executing flexibility allows the contractor to address uncertainties rather than applying to or discussing with the owner about everything or details. On the one hand, when the terms of the formal contract are not applicable to the new situation or unexpected circumstances occur, it may cost more manpower, material resources and time to renegotiate and sign the formal contract, and both parties can resort to the relationship to deal with the new situation quickly and economically. On the other hand, due to the constraints of signing costs, it is difficult to specify all details in a formal project contract. At this time, owners are more inclined to solve problems through cooperation and mutual trust and give contractors more freedom to deal with problems by themselves rather than strictly reviewing or approving every business and making up for the incompleteness of formal contracts with lower costs.

\subsection{Ongoing Trust}

Trust is not a result-oriented concept but a process-oriented concept [22]. Especially in the construction project, the trust relationship between parties is not an isolated event but a process gradually formed in the project's implementation and mutual interaction, namely, ongoing trust (OT). It reflects the expectation about the reliability of the other party, which generates from specific actions [23]. Compared with the initial trust, ongoing trust between parties has a more sustained and significant impact on the cooperation intention, behavior and attitude of both parties [24]. Therefore, this study focuses on the contractor's ongoing trust in the process of project implementation and treats it as a positive intention that believes the owner will not harm his interests, even if he needs to take a certain amount of risk.

Based on three classical models of trust applied to the project situation proposed by Hartman [25], Rousseau et al. [26] and Lewicki and Bunker [27], Yang and Shuai [28] discussed and found three sources of trust in Chinese construction projects, competence, relation and intuition trust. In this study, as the basis of transaction, the contract provides institutional support and guarantee for the activities of both parties. Compared with the initial intuition trust, the institution provided by the formal or informal contract will play greater influence on the contractor's mind and behavior, correspondingly becoming the trust's source. Therefore, this study combined the models from Yang and Shuai [28] and Rousseau, Sitkin, Burt and Camerer [26] and argued that the formation sources of ongoing trust includes the owner's competence, both parties' relationship and the institution.

\subsection{Justice Perception}

Justice reflects an important moral quality, which occurs when one party believes that a decision, outcome or process is balanced and correct [29]. It is not so much an objective outcome as a subjective and relative evaluation of an action or outcome [30], namely, justice perception (JP). Inter-organizational equity plays an important role in responding to internal and external environmental uncertainties and creates a basis for inter-organizational cooperation. If one party feels the existence of fairness in the trading activity, the convenience will hold a positive state for the future result, invest more resources into the trading and reduce opportunistic behaviors. On the contrary, the lack of fairness 
will lead to conflict and even the termination of the transaction relationship. In the context of construction projects, owners and contractors usually have conflicting goals, interests and concepts. The perception of fairness is of great value to the management of these conflicts, which can effectively reduce the risk of conflicts and promote the generation of cooperative behaviors. Combined with the construction context, we define justice perception as a project contractor's subjective perception or evaluation of the appropriateness of the owner's decision, behavior and project results in the project process.

Furthermore, the formation of justice perception at the level of individuals and organizations mainly comes from the reasonability and equality of the distribution, procedures and interactions [31], which is recognized by scholars and widely used at individual and organizational levels [32]. Among them, distributive justice perception represents an individual's sense of fairness in the distribution of results, such as resources and salary, and focuses on the distribution of resources or results, as well as subjective judgment on input and return. In inter-organizational transactions, when one party believes that the outcome of the transaction is fair compared to its contribution, this convenience generates distributive justice perception. Procedural justice perception refers to individuals' perception of formal decision-making procedures and related policies, reflecting fairness in the process. It depends on whether the decision-making process is open, transparent and impartial. Fairness is perceived when one party believes it can control or intervene in the process. It can be seen that procedural fairness involves fairness in the process of outcome distribution and emphasizes control power in the process of distribution. The perception of interactive justice is one party's subjective perception of the quality of the relationship, emphasizing the important role of respect, honesty and politeness in interaction. This fairness also includes interpersonal fairness and information fairness. The former refers to whether the two parties treat each other politely and respectfully, while the latter reflects the degree and state of information exchange between the two parties. When one party feels the respect, courtesy and full exchange of information from the other party during the interaction, the interaction will have a sense of fairness.

\subsection{Contractors' Cooperative Behavior}

Cooperative behavior (CB) is the effort that individuals are willing to make efforts for others in order to complete tasks. It is always accompanied by a certain degree of sacrifice to achieve mutual help [33]. In line with Zhang et al. [34], this study defines the contractor's cooperative behavior as a series of adaptive and mutually beneficial efforts and coordination taken by the contractor, who is willing to take certain risks in order to achieve the common goals or interests with the owner in the project.

According to literature, there are mainly two perspectives about the dimensions of cooperative behavior. One focuses on the characters of cooperative behavior, such as in-role and extra-role behavior [35]. The other one identifies dimensions according to the content structure, such as information exchange, shared problem solving and highlighted flexibility from Pearce [36]. Due to the complication and diversity of contractor's behavior, it is hard to accurately classify a kind of behavior into one attribute. Thus, this study more agrees with Pearce [36] and mainly focuses on three kinds of cooperative behavior.

\section{Hypotheses Development}

\subsection{Contractual Flexibility and Contractors' Cooperative Behavior}

The contract with high completeness clearly prescribes different aspects of complex transactions in advance, such as working scope, conflict resolution procedures, contingencies and critical milestones [37], which clearly specify what is and what is not allowed [35]. This enhances the transparency of the trading and forms an effective supervision over opportunistic behavior to provide effective guidance for the future [38]. When disputes arise, the contractor can cooperate with the owner according to the rules and fulfill responsibilities [39] instead of being concerned about opportunistic behavior [40]. Meanwhile, the 
detailed contract also clarifies both parties' expectations, which can improve the consistency of objectives [41] and promote the continuous and cooperative activities [42].

The active and passive selection space of flexible contract creates a buffer zone and awards the contractor the right to seek fair return, which can decrease contractors' concerns about the unknown risk and restrain opportunistic behavior [4]. Meanwhile, this flexibility reflects a good future expectation and expresses the inherent willingness to continue the transaction, which can encourage the contractor to assume responsibility and reduce the possibility of severe losses. In addition, the selection space also provides an adjustment mechanism, and permits the contractor to cooperate according to specific situations, instead of sticking to inapplicable clauses [21].

On the other hand, contract executing flexibility takes the favorable relationship as flexible elements and combines them into the contracting through relational competence [20]. Instead of sticking to the initial clauses [3], it creates a buffer space and allows the contractor to fully discuss the project process and tasks with the owner and better understand uncertainties or problems. Such a clear post-definition is a key factor to promote the contractor to solve problems through cooperation [43] and response to the continuously trading environment effectively [3]. Secondly, instead of referring to the owner for everything or the complex and time-consuming formal negotiation process, contract executing flexibility supports the contractor to independently deal with some risks in a mutually beneficial way. This in turn strengthens the inter-organizational ties and positive emotions and improves the transaction satisfaction, forming the basis for the contractor's cooperative attitude [44]. Thereby, we hypothesize:

Hypothesis 1 (H1). Contract content flexibility (H1a) and executing flexibility (H1b) affect the contractor's cooperative behavior positively.

\subsection{Parallel Mediation Effect of Ongoing Trust and Justice Perception}

\subsubsection{Mediation Effect of Ongoing Trust}

The pursuit of completeness is helpful to define the contractor's role [3]. When signing this flexible contract, the contractor will be committed to the transaction [45], and this will be further reflected as the acceptance and performance of responsibilities, which promotes institution-oriented trust. Meanwhile, formal, clear and detailed clauses provide a formal platform to prove that the owner has enough competences to fulfill his responsibilities, such as capability of payment, which is helpful for the emergence and persistence of trust [46]. Secondly, the selection space provides an opportunity for the contractor to communicate and negotiate according to changes and enhances favorable mutual interaction that is beneficial for trust [47].

On the other hand, in the contracting process, executing flexibility coordinates the parties' interests according to new changes or uncertainties in a flexible way. This is helpful to develop a good relationship and enhance or maintain a trust relationship [47]. Furthermore, the usage of an informal contract usually means that the contractor believes the flexible execution can effectively safeguard his interests and bring more income than keeping the original contract. This will maintain his good will about the project's returns [48] and create an environment to reduce opportunistic behaviors [47]. Additionally, the flexible authorization mechanism is beneficial to reduce the power imbalance between the parties [49], which further promotes the contractor's satisfaction and contributes to the increase in ongoing trust.

Meanwhile, trust helps to ease the hostile atmosphere between parties, avoid excessive self-protection and even weaken the willingness to adopt opportunistic behavior [50]. Meanwhile, it constitutes the intrinsic motivation to pay more attention to the common interests with the owner [44] and cultivates the partnership between parties [51]. It also creates moral constraints and brings the belief that the owner will cooperate in a reliable, authentic and long-term manner, instead of short-term and self-interested behaviors. Thereby, we hypothesize: 
Hypothesis 2 (H2). Ongoing trust plays a mediation role between contract content $(\mathrm{H} 2 a) /$ executing (H2b) flexibility and cooperative behavior.

\subsubsection{Mediation Effect of Justice Perception}

By designing a relatively complete contract, contract content flexibility clarifies the potential solutions of various contingencies in advance as far as possible [21]. Under this, the contractor's interests are more likely to be integrated with the owner's and be realized through negotiated strategies, which will promote the rationality of profit distribution [52]. Secondly, when some unexpected risks occur, the framework provided by the adaptive clauses supports to resolve matters smoothly and efficiently at the institutional level and avoid disputes between the parties [44]. Moreover, the active and passive selections space gives the contractor the right to participate in the risk decision and realizes the share of risk responsibility reasonably [53]. In short, contract content flexibility forms a mechanism of adaptability to prompt reasonable risk sharing and realize joint decision and good interaction, which further which constitutes the source of justice perception.

On the other hand, in the flexible executing process, the contractor is more likely to focus on the effective dialogue and negotiation with the owner to solve problems. This forms a supplement to the incompleteness of the formal contract [54] and offers the contractor more renegotiation opportunities to jointly negotiate the division of responsibilities and solutions with the owner [20]. In turn, the contractor will make positive judgment about acceptability and reasonability of project outcomes. Secondly, the proper authorization improves the contractor's positive recognition about the relationship and make him believe the executing and interaction with the owner are fair [55]. All of these realizes the reasonable division and response of uncertain results and processes.

Correspondingly, the generation of justice perception will encourage the contractor to form a good will and make efforts towards the common goals, which can effectively curb moral hazard [56] and promote more cooperative behaviors [40]. Specifically, the distribution justice perception means the contractor's efforts are equally rewarded, which can enable him to invest more resources to maintain the partnership and contractual relationship [31,40]. Secondly, when the contractor can fairly participate in the project process, he will believe that his knowledge and ability are affirmed [57] and make efforts to improve the relationship quality [58]. Thirdly, justice from interaction lets the contractor feel him are being treated fairly and stimulates him to act for mutual benefit, even showing a positive behavior beyond the contract [59]. Thereby, we hypothesize:

Hypothesis 3 (H3). Justice perception plays a mediation role between contract content (H3a)/ executing (H3b) flexibility and cooperative behavior.

As discussed above, contractual flexibility builds a mechanism to deal with project uncertainty fairly and reasonably in a less costly and more efficient way. This brings the contractor a high sense of justice, which constitutes the premise of transaction reciprocity and promotes him to behave cooperatively. On the other hand, a flexible contract creates a cooperative atmosphere and reflects the positive expectation for the benign transaction, which helps to create the contractor's ongoing trust. Based on this, the contractor is more likely to focus on the coordination of overall interests and form self-moral constraints, which positively relate to cooperative behavior. Thereby, we hypothesize:

Hypothesis 4 (H4). Ongoing trust and contractor's justice perception play a parallel mediation between contract content ( $\mathrm{H} 4 a)$ )/executing $(\mathrm{H} 4 \mathrm{~b})$ flexibility and cooperative behavior.

\subsection{Chain Mediation Effect of Ongoing Trust and Justice Perception}

Justice perception has a positive effect on the formation of continuous trust. Actually, justice is a necessary condition for trust [60]. The formation and maintenance of ongoing trust derives from the understanding that his investment is rewarded and treated [24]. When the contractor is to obtain a fair, reasonable income, a reliable system program as 
well as the owner's friendliness, he will believe that the owner can give reasonable returns, which promotes the contractor to continue to trust the owner. That is to say, the contractor with a justice perception believes the owner treats him fairly and his interests and rights could be protected and guaranteed effectively in the future, which enable him to be satisfied with the project's process and results and thus be willing to trust, i.e., to be vulnerable to the owner [61].

Furthermore, based on the above analysis, contract content and execution flexibility have a positive impact on the contractor's justice perception. Specifically, project contract flexibility can be regarded as a negotiated concession in the transaction relationship, which can form a positive attitude in the form of reciprocity between the parties to the transaction. This cooperative trading environment reduces the threat of opportunism and is conducive to the success of the social exchange process and the creation of value; that is, contract flexibility can promote sustainable and fair behavior. Accordingly, contract content and execution flexibility may promote contractors' cooperative behavior through the internal relationship path "fairness perception-continuous trust". Thereby, we hypothesize:

Hypothesis 5 (H5). Contractor's justice perception affects ongoing trust positively.

Hypothesis 6 (H6). Contractor's justice perception and ongoing trust play a chain mediation effect between contract content $(\mathrm{H} 6 \mathrm{a}) /$ executing $(\mathrm{H} 6 \mathrm{~b})$ flexibility and cooperative behavior.

\section{Research Methods}

\subsection{Sampling and Data Collection}

This study adopted a questionnaire survey to collect data from project contractors in Chinese construction projects. The respondents needed to have more than 1 year of project work experience and understand the signing and execution of project contracts. Actually, the respondents are mainly from the following positions: project manager, technical engineer and contract manager, who have a deep understanding about project contracting. At the same time, respondents were required to answer the questionnaire based on the experience of specific construction projects they have participated in or were currently participating in. Based on the specific project, relevant data are collected by focusing on the content and process of a single project contract, so as to improve the reliability and validity of data.

We found the survey samples in the field of construction projects and distributed questionnaires through Dalian University of Technology and Sun Yat-sen University University Alumni Association, MBA students' training courses and enterprise research programs. Researchers were able to get close to interviewees to ensure that they come from the construction project industry and have some experience in project management or participation. Moreover, an electronic questionnaire was issued to collect data through an online survey platform. Actually, the electronic questionnaire was distributed with the help of the above respondents. The questionnaire was further expanded to the respondents' related enterprises and peers, forming a "snowball" chain questionnaire distribution and acquisition, expanding the distribution range.

The data collection lasted for 6 months from July 2018 to December 2018. A total of 438 questionnaires were issued, and 387 questionnaires were collected, which lasted for 6 months, and then 317 valid questionnaires were obtained. As shown in Table 1, the differences between men and women are relatively obvious, and the respondents are mostly with bachelor's or master's degrees, which is consistent with the Chinese construction industry that there are more male practitioners or managers who generally have a higher education degree. At the same time, the respondents mainly include project managers and contract managers who have extensive work experience, and the quantity distributions of age, working years and the number of projects are relatively uniform, and the variance of each variable is small, which indicates that the sample data are distributed evenly and representatively. 
Table 1. Demographic characteristics of the sample $(N=317)$.

\begin{tabular}{|c|c|c|c|c|c|}
\hline Demographic Variables & Type & Value & $\%$ & Mean & Variance \\
\hline \multirow{2}{*}{ Gender } & Male & 1 & $76 \%$ & \multirow{2}{*}{0.76} & \multirow{2}{*}{0.43} \\
\hline & Female & 0 & $24 \%$ & & \\
\hline \multirow{4}{*}{ Age } & $\leq 30$ & 1 & $22 \%$ & \multirow{4}{*}{2.29} & \multirow{4}{*}{0.92} \\
\hline & $30-35$ & 2 & $37 \%$ & & \\
\hline & $35-40$ & 3 & $31 \%$ & & \\
\hline & $\geq 40$ & 4 & $10 \%$ & & \\
\hline \multirow{5}{*}{ Education } & College graduate or below & 1 & $11 \%$ & \multirow{5}{*}{2.43} & \multirow{5}{*}{0.80} \\
\hline & Bachelor & 2 & $43 \%$ & & \\
\hline & Master & 3 & $38 \%$ & & \\
\hline & Ph.D. or above & 4 & $8 \%$ & & \\
\hline & Project manager & 1 & $34 \%$ & & \\
\hline \multirow{3}{*}{ Position } & Project director & 2 & $22 \%$ & \multirow{3}{*}{2.25} & \multirow{3}{*}{1.08} \\
\hline & Contract manager & 3 & $29 \%$ & & \\
\hline & Technical engineer & 4 & $15 \%$ & & \\
\hline \multirow{4}{*}{ Working Experience } & $<2$ years & 1 & $25 \%$ & \multirow{5}{*}{2.26} & \multirow{4}{*}{0.97} \\
\hline & $3-5$ years & 2 & $36 \%$ & & \\
\hline & $6-10$ years & 3 & $27 \%$ & & \\
\hline & $>11$ years & 4 & $12 \%$ & & \\
\hline \multirow{4}{*}{ Number of participated projects } & $<2$ & 1 & $13 \%$ & & \multirow{4}{*}{0.81} \\
\hline & $3-5$ & 2 & $42 \%$ & \multirow{3}{*}{2.40} & \\
\hline & $6-10$ & 3 & $37 \%$ & & \\
\hline & $>11$ & 4 & $8 \%$ & & \\
\hline \multirow{5}{*}{ Project type } & Engineering Design & 1 & $23 \%$ & \multirow{5}{*}{2.71} & \multirow{5}{*}{1.25} \\
\hline & EPC & 2 & $20 \%$ & & \\
\hline & Building & 3 & $27 \%$ & & \\
\hline & Decoration & 4 & $22 \%$ & & \\
\hline & Others & 5 & $8 \%$ & & \\
\hline \multirow{4}{*}{ Project size } & $<\mathrm{CNY} 10$ bn & 1 & $19 \%$ & \multirow{5}{*}{2.47} & \multirow{5}{*}{1.10} \\
\hline & CNY $10-50$ bn & 2 & $38 \%$ & & \\
\hline & CNY 50-100 bn & 3 & $22 \%$ & & \\
\hline & CNY 100-200 bn & 4 & $16 \%$ & & \\
\hline \multirow{4}{*}{ Contract formality } & $>$ CNY 200 bn & 5 & $5 \%$ & & \\
\hline & Fixed price contract & 1 & $32 \%$ & \multirow{3}{*}{1.98} & \multirow{3}{*}{0.78} \\
\hline & Bill of quantities contract & 2 & $38 \%$ & & \\
\hline & Unit Price List Contract & 3 & $30 \%$ & & \\
\hline
\end{tabular}

\subsection{Measurement}

We selected classical scales with reliability and validity and translated all the items between Chinese and English. Through the comparison and analysis of the Chinese and English scales, we designed the questionnaire and discussed the initial measurement scales with professors, lecturers, doctoral students, etc., in the form of emails or interviews before the formal distribution. Based on the feedback, the questionnaire was modified and revised.

The questionnaire was tested by means of small-scale questionnaire distribution and data collection. A total of 150 questionnaires were issued, and 113 valid questionnaires were obtained as pre-survey data to test the reliability and validity of the questionnaire. After testing and modifying, the final questionnaire includes 37 items of 5 variables, as shown in Appendix A. The respondents were asked to indicate the extent of their agreement with statements, using a Likert scale ranging from 1 'strongly disagree' to 5 'strongly agree'. Considering the sample number is about 8.5 times of the items, the requirement of 5-10 times was met [62].

\subsubsection{Contractual Flexibility}

The items to measure project contractual flexibility were adopted from the scale in Song, Zhu, Klakegg and Wang [12], which has been proven to have high reliability and validity and be applicable to the Chinese construction industry. As indicated in 
Appendix A, five items were used to capture contract content flexibility, and the other five ones were used to measure contract executing flexibility.

\subsubsection{Contractors' Cooperative Behavior}

The measurement of contractor cooperation behavior mainly refers to the research results of Pearce [36] and Zhang, Zhang, Gao and Ding [34] and used 9 items to measure the behavior in 3 aspects, namely, information exchange, shared problem solving and highlighted flexibility. All the items were revised to be applicable in the construction project context (Appendix A).

\subsubsection{Justice Perception and Ongoing Trust}

Contractors' justice perception is an intermediary variable in this study. Its measurement mainly refers to the research results of Poppo and Zhou [40], Yaling et al. [63] and Colquitt et al. [64] and includes 9 items, which were modified considering the Chinese construction practice and measured distribution, procedure and interaction justice, as displayed in Appendix A.

The measurement for contractor's ongoing trust was based on the items from the research work of Rousseau, Sitkin, Burt and Camerer [26], Khalfan, Mcdermott and Swan [24] and Yang and Shuai [28] and explores ongoing trust using 9 items from 3 aspects, namely, capability, institution and relation. The scale was modified and adapted considering the Chinese construction practice.

\subsection{Control Variables}

This study mainly has controlled for two kinds of variables, namely, project properties (project type and size) and relationship properties (prior cooperation and future business prospects), to eliminate potential influences from other factors. The type and size of a project may affect its implement $[65,66]$. Meanwhile, prior relationships (PR) between organizational partners may reduce opportunism [67], and future business (FB) prospects also significantly influence contractors' behavior [35].

\subsection{Common Method Bias}

Two tests were adapted to eliminate potential common method bias, including program control and statistical control [68]. Firstly, we analyzed the accuracy and comprehensibility of the scale by Chinese-English mutual translation and experts' discussion to ensure the scientific nature and comprehensibility of questionnaire items. The respondents are required to answer the questionnaire based on specific construction project to improve the reliability and effectiveness of the data. Meanwhile, we clearly stated the purpose of this and promised to keep their confidential information in order to let them answer questions with an open attitude and true view. Additionally, Harman single factor test was performed for unrotated factor analysis of all the items. The results showed there are five common factors, and the explanatory power of first one is $45.9 \%(<50 \%)$, which means the common method bias in the study is not a major concern.

\section{Model Evaluation}

\subsection{Measurement Model Evaluation}

Table 2 shows that the KMO values of five research variables are over 0.50 , and the chi-square values of Bartlett's spherical test are all significant, indicating the research data are suitable for exploratory factor analysis. Meanwhile, Cronbach's coefficient of each variable is greater than 0.8 , the CITC value of each item is greater than 0.5 , the factor load is greater than 0.6 and the $\mathrm{KMO}$ value is greater than $50 \%$. These indicate that the formal survey measurement scale has a high internal consistency and structural validity. 
Table 2. Reliability test results of potential variables.

\begin{tabular}{|c|c|c|c|c|c|c|c|}
\hline Item & CITC & Cronbach's $\alpha$ & Rotated & Factor Loading & $\begin{array}{c}\text { Accumulative } \\
\text { Explained Variance } \\
\text { Variation \% }\end{array}$ & KMO & $\begin{array}{l}\text { Bartlett's Test } \\
\text { of Sphericity }\end{array}$ \\
\hline CF1 & 0.786 & \multirow{10}{*}{0.857} & 0.866 & & \multirow{10}{*}{$66.041 \%$} & \multirow{10}{*}{0.881} & \multirow{10}{*}{$\begin{array}{c}\text { Approx. Chi-Square: } \\
1517.510 \\
\text { df: } 45 \\
\text { Sig. } 0.000\end{array}$} \\
\hline CF2 & 0.710 & & 0.820 & & & & \\
\hline CF3 & 0.768 & & 0.861 & & & & \\
\hline CF4 & 0.726 & & 0.807 & & & & \\
\hline CF5 & 0.605 & & 0.707 & & & & \\
\hline EF1 & 0.715 & & & 0.810 & & & \\
\hline EF2 & 0.665 & & & 0.780 & & & \\
\hline EF3 & 0.634 & & & 0.759 & & & \\
\hline EF4 & 0.715 & & & 0.828 & & & \\
\hline EF5 & 0.625 & & & 0.751 & & & \\
\hline JP1 & 0.717 & \multirow{9}{*}{0.919} & & 0.779 & & & \multirow{9}{*}{$\begin{array}{c}\text { Approx. Chi-Square: } \\
\text { 1717.096 } \\
\text { df: } 36 \\
\text { Sig. } 0.000\end{array}$} \\
\hline $\mathrm{JP2}$ & 0.639 & & & 0.709 & & & \\
\hline JP3 & 0.696 & & & 0.761 & & & \\
\hline JP4 & 0.742 & & & 0.803 & & & \\
\hline JP5 & 0.686 & & & 0.755 & $60.870 \%$ & 0.922 & \\
\hline JP6 & 0.752 & & & 0.817 & & & \\
\hline JP7 & 0.694 & & & 0.768 & & & \\
\hline JP8 & 0.756 & & & 0.820 & & & \\
\hline JP9 & 0.737 & & & 0.804 & & & \\
\hline OT1 & 0.560 & \multirow{9}{*}{0.829} & & 0.787 & \multirow{9}{*}{$72.316 \%$} & \multirow{9}{*}{0.817} & \multirow{9}{*}{$\begin{array}{c}\text { Approx. Chi-Square: } \\
\text { 1076.081 } \\
\text { df: } 36 \\
\text { Sig. } 0.000\end{array}$} \\
\hline OT2 & 0.517 & & & 0.874 & & & \\
\hline OT3 & 0.476 & & & 0.830 & & & \\
\hline OT4 & 0.611 & & & 0.813 & & & \\
\hline OT5 & 0.515 & & & 0.826 & & & \\
\hline OT6 & 0.520 & & & 0.832 & & & \\
\hline OT7 & 0.577 & & & 0.807 & & & \\
\hline OT8 & 0.529 & & & 0.776 & & & \\
\hline OT9 & 0.511 & & & 0.811 & & & \\
\hline CB1 & 0.665 & \multirow{9}{*}{0.892} & & 0.742 & & & \multirow{9}{*}{$\begin{array}{c}\text { Approx. Chi-Square: } \\
1278.166 \\
\text { df: } 36 \\
\text { Sig. } 0.000\end{array}$} \\
\hline CB2 & 0.616 & & & 0.700 & & & \\
\hline CB3 & 0.640 & & & 0.723 & & & \\
\hline CB4 & 0.620 & & & 0.705 & & & \\
\hline CB5 & 0.617 & & & 0.706 & $53.616 \%$ & 0.907 & \\
\hline CB6 & 0.675 & & & 0.757 & & & \\
\hline CB7 & 0.674 & & & 0.757 & & & \\
\hline CB8 & 0.674 & & & 0.757 & & & \\
\hline CB9 & 0.671 & & & 0.755 & & & \\
\hline
\end{tabular}

The results of principal component analysis showed that the standardized factor load coefficients of all latent variables are distributed between 0.700 and 0.874 , over 0.50 [69], and $p$ values are less than 0.001 . The reliability of the internal indicators within each variable was ensured as the values of composite reliability (CR) are over 0.7 [70]. The convergent validity of the factors was achieved as the values of the average variance extracted (AVE) are greater than 0.5. The AVE of each factor is higher than its squared correlation with other factors (see Table 3), and each measurement item has the highest loading on the corresponding factor (see Table 4). These together indicate a satisfactory discriminate validity of the factors [71]. Overall, the measures in this study have adequate reliability and validity. 
Table 3. The AVE and its square root, correlation and CR of potential variables.

\begin{tabular}{|c|c|c|c|c|c|c|c|c|c|c|c|}
\hline Variable & Type & Size & PR & FB & CF & EF & JP & OT & CB & AVE & CR \\
\hline \multicolumn{12}{|l|}{ Type } \\
\hline Size & $0.917^{\mathrm{a}}$ & & & & & & & & & & \\
\hline PR & $0.136^{\mathrm{b}}$ & $0.151^{\mathrm{a}}$ & & & & & & & & & \\
\hline FB & 0.092 & 0.099 & -0.002 & & & & & & & & \\
\hline $\mathrm{CF}$ & 0.051 & 0.021 & 0.073 & $0.134^{b}$ & 0.814 & & & & & 0.663 & 0.907 \\
\hline $\mathrm{EF}$ & $0.133^{b}$ & $0.120^{b}$ & $0.245^{\mathrm{a}}$ & 0.049 & $0.333^{a}$ & 0.786 & & & & 0.618 & 0.89 \\
\hline $\mathrm{JP}$ & $0.460^{\mathrm{a}}$ & $0.488^{a}$ & $0.163^{\mathrm{a}}$ & $0.112^{b}$ & $0.433^{a}$ & $0.359^{a}$ & 0.780 & & & 0.609 & 0.933 \\
\hline OT & 0.076 & 0.097 & $0.113^{b}$ & $0.130^{b}$ & $0.422^{a}$ & $0.394^{\mathrm{a}}$ & $0.426^{\mathrm{a}}$ & 0.818 & & 0.669 & 0.948 \\
\hline $\mathrm{CB}$ & $0.175^{\mathrm{a}}$ & $0.191^{\mathrm{a}}$ & $0.140^{b}$ & $0.239^{\mathrm{a}}$ & $0.516^{\mathrm{a}}$ & $0.365^{\mathrm{a}}$ & $0.501^{\mathrm{a}}$ & $0.500^{\mathrm{a}}$ & 0.734 & 0.539 & 0.913 \\
\hline
\end{tabular}

Note: The diagonal elements (i.e., bold values) are the square roots of AVEs. Unadjusted correlations appear below the diagonal. ${ }^{\mathrm{a}}$ Correlation is significant at the 0.01 level (2-tailed). ${ }^{\mathrm{b}}$ Correlation is significant at the 0.05 level (2-tailed).

Table 4. Cross loading among observational variables.

\begin{tabular}{|c|c|c|c|c|c|}
\hline & CF & EF & JP & OT & CB \\
\hline CF1 & 0.190 & 0.004 & 0.007 & 0.008 & 0.013 \\
\hline CF2 & 0.101 & 0.002 & 0.004 & 0.004 & 0.007 \\
\hline CF3 & 0.145 & 0.003 & 0.006 & 0.006 & 0.010 \\
\hline CF4 & 0.094 & 0.002 & 0.004 & 0.004 & 0.006 \\
\hline CF5 & 0.066 & 0.001 & 0.003 & 0.003 & 0.004 \\
\hline EF1 & 0.003 & 0.225 & 0.006 & 0.010 & 0.005 \\
\hline EF2 & 0.002 & 0.157 & 0.004 & 0.007 & 0.003 \\
\hline EF3 & 0.002 & 0.128 & 0.003 & 0.006 & 0.003 \\
\hline EF4 & 0.002 & 0.191 & 0.005 & 0.009 & 0.004 \\
\hline EF5 & 0.002 & 0.117 & 0.003 & 0.005 & 0.002 \\
\hline JP1 & 0.002 & 0.002 & 0.084 & 0.003 & 0.003 \\
\hline JP2 & 0.001 & 0.002 & 0.069 & 0.002 & 0.003 \\
\hline JP3 & 0.002 & 0.002 & 0.077 & 0.002 & 0.003 \\
\hline JP4 & 0.002 & 0.003 & 0.100 & 0.003 & 0.004 \\
\hline JP5 & 0.002 & 0.002 & 0.081 & 0.002 & 0.003 \\
\hline JP6 & 0.003 & 0.003 & 0.135 & 0.004 & 0.005 \\
\hline JP7 & 0.002 & 0.003 & 0.101 & 0.003 & 0.004 \\
\hline JP8 & 0.003 & 0.003 & 0.136 & 0.004 & 0.005 \\
\hline JP9 & 0.003 & 0.003 & 0.123 & 0.004 & 0.004 \\
\hline OT1 & 0.003 & 0.005 & 0.003 & 0.076 & 0.006 \\
\hline OT2 & 0.002 & 0.004 & 0.003 & 0.066 & 0.005 \\
\hline OT3 & 0.002 & 0.003 & 0.002 & 0.052 & 0.004 \\
\hline OT4 & 0.004 & 0.007 & 0.005 & 0.114 & 0.009 \\
\hline OT5 & 0.003 & 0.005 & 0.004 & 0.086 & 0.007 \\
\hline OT6 & 0.003 & 0.005 & 0.004 & 0.083 & 0.006 \\
\hline OT7 & 0.003 & 0.005 & 0.004 & 0.091 & 0.007 \\
\hline OT8 & 0.002 & 0.004 & 0.003 & 0.070 & 0.005 \\
\hline OT9 & 0.003 & 0.004 & 0.003 & 0.074 & 0.006 \\
\hline CB1 & 0.005 & 0.002 & 0.004 & 0.007 & 0.089 \\
\hline CB2 & 0.004 & 0.002 & 0.004 & 0.005 & 0.072 \\
\hline CB3 & 0.004 & 0.002 & 0.004 & 0.006 & 0.078 \\
\hline CB4 & 0.003 & 0.002 & 0.003 & 0.005 & 0.068 \\
\hline CB5 & 0.004 & 0.002 & 0.004 & 0.006 & 0.077 \\
\hline CB6 & 0.005 & 0.003 & 0.005 & 0.007 & 0.097 \\
\hline CB7 & 0.005 & 0.003 & 0.005 & 0.008 & 0.106 \\
\hline CB8 & 0.005 & 0.003 & 0.005 & 0.008 & 0.102 \\
\hline CB9 & 0.005 & 0.003 & 0.005 & 0.007 & 0.096 \\
\hline
\end{tabular}

\subsection{Structural Model Evaluation}

\subsubsection{Test and Modification of the Initial Model}

There are 37 observed variables in this study, which can meet the T rule of model recognition. The measurement items of each latent variable are more than three. Therefore, 
the structural model is recognizable. This study used Amos24.0 to test the initial structure model. As shown in Table 5, although all indices have not reached the critical standards, the overall results are satisfactory. According to literature, all paths in the model have theoretical significance and can be retained. Therefore, this study modified the initial model according to model fitting correction index, which shows that some covariance correction indices of the error terms are high. Thus, this study adjusted the correlation paths until no significant results of each correction index existed, and the overall model fittings were continuously improved. The final fitting results and the model(M0) are shown in Table 5 and Figure 1, respectively. The modified error terms are all belonging to the same variable. The overall fitting degree of the structural model is good, which meets the critical value requirements, and the model passed the test.

Table 5. The overall fitting results of the initial and modified models.

\begin{tabular}{ccccccc}
\hline Fitting Index & $\chi^{2} / \mathbf{d f}$ & RMSEA & GFI & IFI & TLI & CFI \\
\hline Initial Model & 1.959 & 0.55 & 0.812 & 0.899 & 0.890 & 0.898 \\
\hline Modified Model & 1.077 & 0.016 & 0.901 & 0.992 & 0.991 & 0.992 \\
\hline Critical value & $<2$ & $<0.08$ & $>0.90$ & $>0.90$ & $>0.90$ & $>0.90$ \\
\hline
\end{tabular}

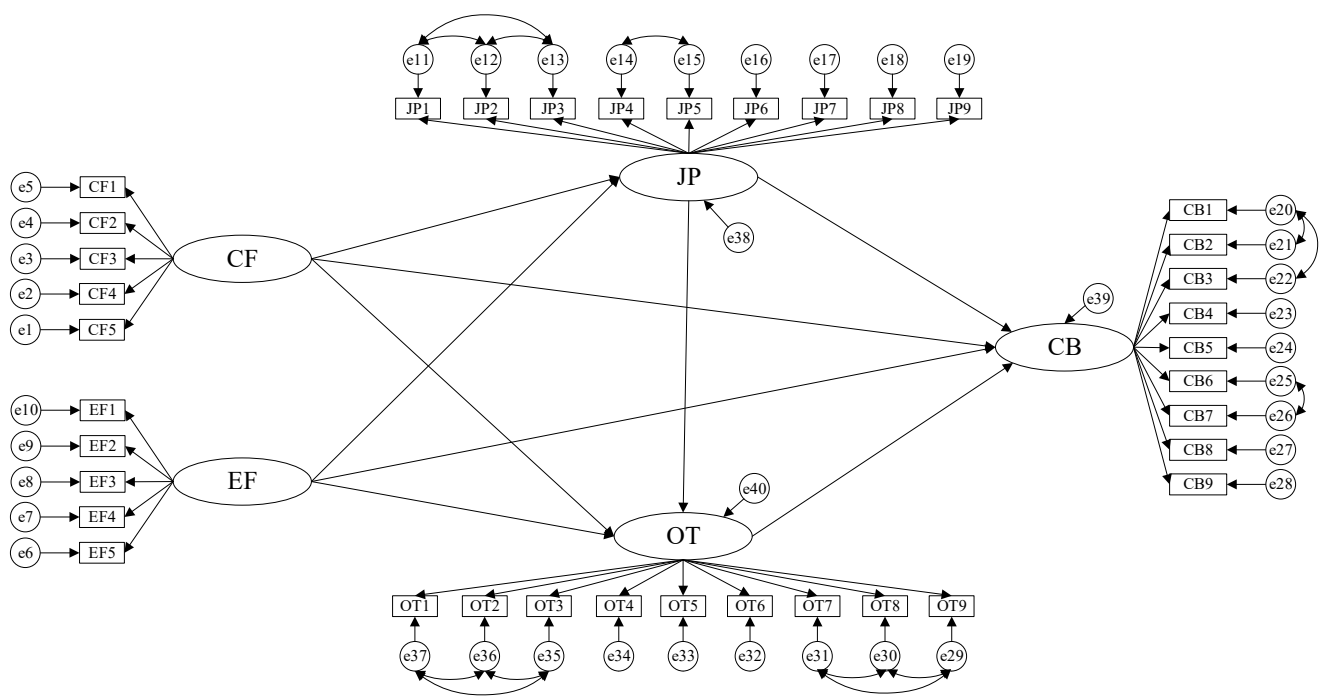

Figure 1. The modified model structure.

\subsubsection{Path Coefficient Analysis of Structure Model}

Table 6 shows that H1a failed the test $(\beta=0.067, p>0.05)$, while the other eight paths are confirmed and $\mathrm{H} 1 \mathrm{~b}$ and $\mathrm{H} 5$ passed. This means that project contract content flexibility does not affect the contractor's cooperative behavior directly. Contract executing flexibility (0.274), justice perception (0.33) and ongoing trust (0.304) significantly affect cooperative behavior. Meanwhile, the positive impacts of contractual flexibility (content and executing) on justice perception or ongoing trust exist. Justice perception has a positive impact on ongoing trust (0.304). 
Table 6. Standardized path coefficient of structural equation model.

\begin{tabular}{|c|c|c|c|c|c|}
\hline Path & $\begin{array}{l}\text { Unstandardized } \\
\text { Path Coefficient }\end{array}$ & $\begin{array}{c}\text { Standardized } \\
\text { Path Coefficient }\end{array}$ & S.E. & C.R.(T) & $p$ \\
\hline 1. $\mathrm{CB}<-\mathrm{CF}$ & 0.107 & 0.109 & 0.059 & 1.834 & 0.067 \\
\hline 2. $\mathrm{CB}<--\mathrm{EF}$ & 0.300 & 0.274 & 0.075 & 3.996 & $* * *$ \\
\hline 3.JP $<-C F$ & 0.357 & 0.278 & 0.083 & 4.285 & $* * *$ \\
\hline 4.JP<——EF & 0.537 & 0.377 & 0.098 & 5.456 & $* * *$ \\
\hline $5 . \mathrm{OT}<-\mathrm{CF}$ & 0.115 & 0.175 & 0.045 & 2.534 & $*$ \\
\hline $6 . \mathrm{OT}<-\mathrm{EF}$ & 0.214 & 0.295 & 0.056 & 3.814 & $* * *$ \\
\hline 7.CB <— JP & 0.172 & 0.223 & 0.051 & 3.362 & $* * *$ \\
\hline 8.CB $<-$ OT & 0.458 & 0.304 & 0.118 & 3.888 & $* * *$ \\
\hline $9 . \mathrm{OT}<-\mathrm{PF}$ & 0.155 & 0.304 & 0.040 & 3.887 & $* * *$ \\
\hline
\end{tabular}

\subsubsection{Preliminary Mediation Effect Test}

This study used PROCESS Model 4 for SPSS Macro [72] to estimate 4 simple mediation models, with 5000 resamples and bias-corrected $95 \%$ CI. The models and results are shown in Table 7. According to the results, justice perception and ongoing trust play a partial mediation effect between contractual flexibility (contract content and executing flexibility) and the contractor's cooperative behavior. $\mathrm{H} 2$ and $\mathrm{H} 3$ are verified.

Table 7. The mediation effect tests of simple mediation models.

\begin{tabular}{ccccccc}
\hline & & Value & T/Z & $p$ & LLCI & ULCI \\
\hline & Total effect & 0.4229 & 10.3598 & $* * *$ & 0.3426 & 0.5033 \\
& Direct effect & 0.3073 & 6.9284 & $* * *$ & 0.2201 & 0.3946 \\
M1:CF-JP-CB & Mediation effect & 0.1156 & & & 0.0726 & 0.1704 \\
& Sobel test & 0.1156 & 4.7341 & $* * *$ & & \\
& Direct effect & 0.3125 & 7.3985 & $* * *$ & 0.2294 & 0.3956 \\
M2:CF-OT-CB & Mediation effect & 0.1105 & & & 0.0668 & 0.1670 \\
& Sobel test & 0.1105 & 4.9418 & $* * *$ & & \\
& Total effect & 0.3488 & 6.2931 & $* * *$ & 0.2397 & 0.4578 \\
& Direct effect & 0.2120 & 0.9310 & $* * *$ & 0.1059 & 0.3181 \\
M3:EF-JP-CB & Mediation effect & 0.1368 & & & 0.0815 & 0.2009 \\
& Sobel test & 0.1368 & 4.788 & $* * *$ & & \\
& Direct effect & 0.1899 & 3.4565 & $* * *$ & 0.0818 & 0.2981 \\
M4:EF-OT-CB & Mediation effect & 0.1589 & & & 0.0944 & 0.2396 \\
& Sobel test & & 5.2168 & $* * *$ & & \\
\hline Not* & & & & & &
\end{tabular}

Note: ${ }^{* * *} p<0.001$

\subsubsection{Parallel Mediation Effect Test}

This study includes parallel mediation models and two-stage chain mediation models, namely, M5 (CF-JP/OT-CB), M6 (EF-JP/OT-CB), M7 (CF-JP-OT-CB) and M8 (EF-JP-OT-CB). The test results are shown in Tables 8 and 9.

As Table 8 shows, the mediation effects of justice perception (M5: $\beta=0.0847$, LLCI $=0.0414, \mathrm{ULCI}=0.1343 ; \mathrm{M6}: \beta=0.1017, \mathrm{LLCI}=0.0578, \mathrm{ULCI}=0.1572)$ and ongoing trust (M5: $\beta=0.0900, \mathrm{LLCI}=0.0513, \mathrm{ULCI}=0.1429 ; \mathrm{M} 5: \beta=0.1180, \mathrm{LLCI}=0.0650$, $\mathrm{ULCI}=0.1860$ ) are all significant. It shows that both mediation variables play a parallel mediation role in the two models. Meanwhile, there is no significant difference between the mediation effect of justice perception and ongoing trust in M5 and M6 (M5: C1 $=-0.0053$, $\mathrm{LLCI}=-0.0775, \mathrm{ULCI}=0.0570 ; \mathrm{M6}: \mathrm{C} 1=-0.0163, \mathrm{LLCI}=-0.0908, \mathrm{ULCI}=0.049)$, and their Sobel tests are significant. This means that ongoing trust is indeed another crucial mediation factor and $\mathrm{H} 4$ passes the test. 
Table 8. The mediation effect tests of parallel mediation models.

\begin{tabular}{ccccccc}
\hline & & Value & T/Z & $p$ & LLCI & ULCI \\
\hline & Direct effect & 0.2483 & 5.6098 & $* * *$ & 0.1612 & 0.3354 \\
& Mediation effect & 0.1746 & & & 0.1187 & 0.2446 \\
& JP & 0.0847 & & & 0.0414 & 0.1343 \\
M5:CF-JP/OT-CCB & OT & 0.0900 & & & 0.0513 & 0.1429 \\
& C1(JP-OT) & -0.0053 & & & -0.0775 & 0.0570 \\
& Sobel test(JP) & 0.0847 & 3.6693 & $* * *$ & & \\
& Sobel test(OT) & 0.0900 & 4.2518 & $* * *$ & & \\
& Direct effect & 0.1291 & 2.4116 & $*$ & 0.0238 & 0.2345 \\
& Mediation effect & 0.2197 & & & 0.1421 & 0.3085 \\
& JP & 0.1017 & & & 0.0578 & 0.1572 \\
M6:EF-JP/OT-CCB & OT & 0.1180 & & & 0.0650 & 0.1860 \\
& C1(JP-OT) & -0.0163 & & & -0.0908 & 0.0490 \\
& Sobel test(JP) & 0.1017 & 4.1226 & $* * *$ & & \\
& Sobel test(OT) & 0.1180 & 4.3885 & $* * *$ & & \\
\hline Note* $* p<0.05^{* * *} p<0.001$ & & & & & &
\end{tabular}

Table 9. The mediation effect tests of serial two-mediator models.

\begin{tabular}{ccccccc}
\hline & & Value & T/Z & $p$ & LLCI & ULCI \\
\hline \multirow{4}{*}{ M7 } & Direct effect & 0.2483 & 5.6098 & $* * *$ & 0.1612 & 0.3354 \\
& Mediation effect & 0.1746 & & & 0.1183 & 0.2433 \\
Path1:CF-JP-CB & 0.0847 & & & 0.0404 & 0.1336 \\
& Path2:CF-JP-OT-CB & 0.0309 & & & 0.0121 & 0.0599 \\
Path3:CF-OT-CB & 0.0590 & & & 0.0303 & 0.1004 \\
& (C1)1-2 & 0.0538 & & & -0.0042 & 0.1078 \\
& (C2)1-3 & 0.0256 & & & -0.0333 & 0.0843 \\
(C3)2-3 & -0.0281 & & & -0.0714 & 0.0080 \\
\hline \multirow{4}{*}{ M8 } & Direct effect & 0.1291 & 2.4116 & $*$ & 0.0238 & 0.2345 \\
& Mediation effect & 0.2197 & & & 0.1430 & 0.3169 \\
& Path1:EF-JP-CB & 0.1017 & & & 0.0586 & 0.1565 \\
Path2:EF-JP-OT-CB & 0.0351 & & & 0.0156 & 0.0667 \\
Path3:EF-OT-CB & 0.0828 & & & 0.0410 & 0.1401 \\
(C1)1-2 & 0.0665 & & -0.0469 & 0.1196 \\
& (C2)1-3 & 0.0189 & & & -0.1001 & -0.0047 \\
\hline (C3)2-3 & -0.0477 & & &
\end{tabular}

Note: ${ }^{*} p<0.05,{ }^{* * *} p<0.001$.

\subsubsection{Chain Mediation Effect Test}

In $\mathrm{M7}$, the mediation effect of path 2 is 0.0309 , accounting for $17.70 \%$ of the total mediation effect, and the confidence interval is (LLCI $=0.0121$, ULCI $=0.0599$ ), which means the two-stage chain mediation effect from justice perception to ongoing trust has been verified. Furthermore, comparing the effect difference between paths, it is shown that the independent mediation effect of justice perception or ongoing trust is similar to their the two-stage continuous mediation effect.

In M8, the mediation effect of path 2 is 0.0351 , accounting for $15.98 \%$ of the total mediation effect, and the confidence interval is (LLCI $=0.0156$, ULCI $=0.0667$ ), which means the two-stage mediation effect has been verified. Furthermore, the effect differences of path 1 and 3 (LLCI $=0.0225$, ULCI $=0.1196)$ or path 2 and 3 (LLCI $=-0.1001$, $\mathrm{ULCI}=-0.0047$ ) are significant, which implies that the independent mediation effect of justice perception or ongoing trust is also stronger than the two-stage chain mediation effect.

\section{Discussion}

\subsection{Positive Impact of Contractual Flexibility on Contractor's Cooperative Behavior}

The empirical results show that contract content flexibility has no significant direct effect on contractor's cooperative behavior $(\beta=0.109, p>0.05)$ and H1a is invalid. This is 
different with the findings of Song, Zhu, Klakegg and Wang [12]. Considering we have larger samples, more mediation and control variables and various test methods, which are beneficial to improve the reliability and validity of the model, this finding is a revision and improvement of the previous study. There may be two reasons for this. First, although the improvement of the flexibility in a contract reduces the ambiguity, it cannot directly promote the contractor's willingness and behavior to bear certain risks for the owner. Secondly, the Chinese construction industry is a buyer's market. In this situation, the buffer space provided by the flexible contract content may also become an opportunity for the owner to seek rent. Therefore, the contractor may not be willing to cooperate. Furthermore, compared with the existing research on the content and behavior of contracts, most of them believe that the content of contracts first affects the relationship state of both parties and then affects their behaviors [4,37,38,42]. For example, the existence of the adjustable clause firstly reduces the contractor's worry about the uncertainty of the future and produces trust in the owner, thus reducing their opportunistic behavior and showing more willingness and behavior of cooperation. Thus, the results of this study further confirm this relationship through an empirical analysis. Relatively, contract executing flexibility can construct, reinforce and maintain relational contracts and then strengthen the cooperative basis. This prompts the contractor to form positive self-reinforcement and show more cooperative behavior. On the other hand, contract executing flexibility has a significant direct effect on the cooperative behavior $(\beta=0.274, p<0.001)$. This result verifies the viewpoints of Harris et al. [73] and Kujala, Nystén-Haarala and Nuottila [21].

\subsection{Mediation Effect of Ongoing Trust}

The path coefficients of contractual flexibility (content and executing flexibility) and ongoing trust are significant $(\beta=0.175, p<0.05 ; \beta=0.295, p<0.001)$. This further deepened the discussion of Chow, Cheung and Chan [45] and Manu, Ankrah, Chinyio and Proverbs [46] from the perspective of the contract. At the same time, it also details the research of Shuibo, Junying and Zhenyu [51] about the relationship between contractual flexibility and ongoing trust. Contract content flexibility can stimulate the contractor commitment, good will and inner satisfaction. Contract executing flexibility can reduce the uncertainty in the contracting, maintain the contractor's interests and build benign relationship. These further promote the contractor's positive expectation for the future and maintain the internal sense of trust. Thus, the partner contract relationship helps build contractor's trust [24].

On the other hand, empirical results show that a contractor's ongoing trust has a significant impact on their cooperative behavior $(\beta=0.304, p<0.001)$. This is consistent with the research results of Shuibo, Junying and Zhenyu [51] and Yaling, Huiling, Peng and Yilin [7] in the field of construction projects and further tests the positive relationship between the inner state of the subject and its behavior. This shows that, from a process perspective, ongoing trust is an important antecedent of cooperative behavior. This factor can strengthen the internal motivation of cooperation, form certain moral constraints, and thus reduce opportunistic behavior. Overall, contractual flexibility can indirectly affect contractor's cooperative behavior through the mediation effect of ongoing trust.

\subsection{Mediation Effect of Justice Perception}

The empirical results show that contract content and executing flexibility both have a positive impact on the contractor's justice perception, which also has positive impact on cooperative behavior $(\beta=0.223, p<0.001$ ). Thus, contractual flexibility can effectively affect the subjective judgment of the contractor, which is consistent with the research of [74]. When the contractor believes he is treated fairly in the project, he will respond to the goodwill of the owner, actively cooperate with the owner's activities and take on a cooperative attitude and behavior. In other words, the contractor's justice perception mediates the relationship between contractual flexibility and cooperative behavior, which is consistent with the research results of Luo [58] and Zhang, Zhang, Gao and Ding [34]. 


\subsection{Multiple Mediation Effect of Ongoing Trust and Justice Perception}

According to the test results, contractual flexibility affects the cooperative behavior through the multiple mediation role of ongoing trust and justice perception. Firstly, the independent effect value of justice perception or ongoing trust accounts for about one third of the total effect in M1-4, which means both factors have small and partial mediation effects. Secondly, the parallel mediation effect accounts for about half of the total effect, M5(0.1746) and M6(0.2197). The mediation effect values of ongoing trust are similar to the ones of justice perception in both models. These suggests that ongoing trust is a crucial mediation factor between contractual flexibility and cooperative behavior, except justice perception, which confirmed the importance of integrating both. Thirdly, according to the results of the path coefficient analysis, the contractor's justice perception has a significant positive impact on ongoing trust $(\beta=0.304, p<0.001)$, which confirms the discussions of Khalfan, Mcdermott and Swan [24] and Zhiwei and Ying [61] about justice and trust in construction project. Based on this, both constitute a chain mediation model and have the similar effects in M7 and M8, which also confirmed the value of ongoing trust.

By comparison, the parallel mediation effects are larger than the independent ones, of which the chain mediation effect is similar (M7) to or smaller(M8) than their independent ones. These suggests that the parallel mediation model has the most explanatory power, and the chain one comes third. These further indicate that ongoing trust and justice perception are two crucial mediation factors. Moreover, the two-stage mediation paths have the least mediation effect. That is probably because it is usually more time-consuming to establish ongoing trust through justice, and the justice is more directly reflected in the contractor's behavior rather than the secondary transmission.

Additionally, in M1-8, the multiple mediation effects of two factors between contract executing flexibility and cooperative behavior is stronger than those between the contract content flexibility and cooperative behavior. This may be because the formation of both factors comes from the contractor's subjective understanding and judgment, which is not entirely from the project contract itself but is gradually formed through the activities and interactions of both parties in the project process. In other words, the executing process is more conducive to the contractor's understanding and judgment. Therefore, the flexibility of project contract executing has a greater impact on both.

In summary, justice perception and ongoing trust play significant and multiple mediation effects between contractual flexibility and a contractor's cooperative behavior, among which the parallel ones are most prominent and constitute the main indirect influence paths, which have closer relationship with contract executing flexibility. This suggests that justice and trust are important influencing factors of inter-organizational cooperation and have strong direct effects on cooperation.

\section{Conclusions and Implications}

This study integrates ongoing trust into the relationship model of contractual flexibility and contractor's cooperative behavior from the perspective of inter-organization relationships and aims to reveal the potential and multiple mediation effects of ongoing trust and justice perception. The empirical analyses show that (1) apart from justice perception, ongoing trust is another crucial mediation factor in the relationship. (2) Together with the former, ongoing trust plays significantly multiple mediation effects and constitutes the main indirect influence paths, among which the parallel one is strongest and the chain one comes third. (3) Moreover, both factors are more likely to be impacted by contract executing flexibility, compared with contract content flexibility.

The foundations contribute to build a framework in the construction projects, which explores the relationship among contractual flexibility, justice perception, ongoing trust and cooperative behavior. The results take major relational factors of justice and trust into account and develop the research on the relationship between contractual flexibility and cooperative behavior by deconstructing the internal mechanism. What is more, it reveals the important multiple mediation effect of two relational factors and builds the influence paths. 
Specially, the direct and positive effects of "contract execution flexibility-cooperative behavior", "contract content/execution flexibility-justice perception/ongoing trust" and "justice perception/ongoing trust-cooperative behavior" are confirmed. Secondly, we examined and analyzed the existence of multiple mediating effects of justice perception and ongoing trust (simple mediating, parallel mediating and chain mediating) between project contractual flexibility and cooperative behavior. Through the comparative analysis of each intermediary relationship path, this paper revealed the importance of the parallel mediation effect, which deepens the research on the intermediary relationship path. Again, this study verified the existence of two relationship paths, "contractual flexible-justice perceptions-ongoing trust-cooperative behavior" and "contractual flexible-justice perception/ongoing trust, and cooperative behavior". The above empirical research results verify and support the existing qualitative research and systematically explains the multiple impact paths of contract flexibility on contractor cooperation behavior.

For practitioners, especially project owners, this present research provides some guidance. Firstly, it is important for practitioners to focus on the contract relationship and contract's performance. By improving the level of the contractual flexibility, especially the executing flexibility, the owner can promote the ability to adapt to and adjust the internal and external dynamic environment and then stimulates the contractor's cooperative behavior. Secondly, considering the role of ongoing trust, the owner should pay attention to the equity of the project contract and self-reliability simultaneously. Based on this, a stable trading relationship can be strengthened, which will maintain the contractor's trust, provide reasonable return to the contractor and then motivate him to cooperate.

Notwithstanding the contributions and implications to the academia and practice, this study also has several limitations. This study takes the perspective of a relationship to discuss and carry out the research and mainly focuses on two kinds of relationship factors that reflect bilateral cooperation, namely, justice perception and ongoing trust. Given their partial mediation effect, further research is necessary to identify and discuss other factors and enrich the related conclusion. In addition, the research data in this study come from the Chinese construction industry and are rooted in the Chinese context. In China, although contract laws and regulations are constantly improving and strengthening, the signing and execution of project contracts are still quite arbitrary in practice. Especially for the content and execution of contracts, the social characteristics of "guanxi" often provide more flexibility. However, this flexibility is not always beneficial. The study of the Chinese situation can more effectively discuss the value of beneficial flexibility in the contract content and execution process, improve the understanding of reasonable contract flexibility and then strengthen the project contract management activities. Future research could adopt a cross-cultural perspective and explore whether the two relation factors play the same mediation effects in in different cultural contexts.

Author Contributions: Conceptualization, H.S.; methodology, H.S.; formal analysis, H.S.; investigation, S.T.; resources, H.S.; data curation, H.S.; writing-original draft preparation, H.S.; writingreview and editing, J.H.; project administration, H.S.; funding acquisition, H.S. All authors have read and agreed to the published version of the manuscript.

Funding: This research was funded by the National Natural Science Foundation for Young Scholars of China [No. 72104256], the 68th General Program of China Postdoctoral Science Foundation [No. 2020M683150] and the 2021 Youth Project of Philosophy and Social Sciences of Guangdong Province [No. GD21YTS02].

Institutional Review Board Statement: Ethical review and approval were waived for this study, due to REASON: in China, there is no mandatory requirement for relevant research to be conducted and approval by the Ethics Committee. Meanwhile, the relevant Ethics Committee department does not issue a formal approval document. Therefore, the ethics statements can only be expressed through the authors' relevant statements. And we confirm that all participants in the study were clearly and accurately informed about how the data were used before receiving the questionnaire survey, and they agreed to participate in the research process. 
Informed Consent Statement: Informed consent was obtained from all subjects involved in the study.

Data Availability Statement: Not applicable.

Acknowledgments: Special thanks also go to the respondents who volunteered to answer the questionnaires.

Conflicts of Interest: The authors declare no conflict of interest.

\section{Appendix A}

Table A1. List of items.

Construct
CF1: The contract clauses set a floating range to deal with potential risks or uncertainties.
CF2: The contract clauses provide corresponding solutions for potential risks or uncertainties.
CF3: The contract allows us to supplement, adjust or perfect some clauses for certain problems.
CF4: The renegotiation procedure in the contract is flexible.
CF5: According to the contract, we can easily apply for reasonable changes.
EF1: The owner requires strict implementation of the contract clauses(R).
EF2: The owner allows us to adjust the clauses that are not applicable.
EF3: The owner attaches great importance to the cooperative relationship with us.
EF5: The owner allows us to make our own decisions within certain limits.
$\begin{gathered}\text { Contract } \\ \text { executing flexibility }\end{gathered}$
JP1: The compensation paid to us is reasonable, compared with the risk and responsibility we take or
the contribution we make.
JP2: The control or intervention power we have is reasonable compared to the responsibility or risk we take.
JP3: If our action is beneficial to the project, the owner will give us the corresponding compensation or
return even if there is no relevant stipulation in the contract.
JP4: Disputes were resolved fairly in the performance process.
JP5: We can participate in the decision-making process of the owner.
Justice
perception
JP7: The owner behaved politely to us.
JP8: The owner respects us sincerely.
JP9: The owner will consider our feelings.

OT1: The owner pays the project payment in accordance with the contract.

OT2: The owner kept his promise in the contract.

OT3: The owner has shown a high level of contract management ability.

OT4: we worked with the owner happily in the performance process.

Ongoing trust OT5: We formed a good relationship with the owner in the performance process.

OT6: We share the same values, culture or way of doing things with the owner.

OT7: The contract defines formal communication channels and methods.

OT8: The owner will clarify and explain to us the specific meaning of the contract clauses.

OT9: A clear and definite contract gives us more confidence in the owner.

CB1: We have a full exchange of information with the owner.

CB2: We are willing to provide the owner with more confidential information if it is beneficial to the project.

CB3: We will promptly inform the owner of any changes or events that may affect him.

Contractor's cooperative

behavior
CB4: In order to promote the implementation of the project, we undertake our responsibilities.

CB5: We work with the owner to solve the problem instead of passing it on to him.

CB6: We take the initiative to ensure the normal operation of our partnership. CB7: We are open to contract modification and adjustment.

CB8: When unexpected events occur, we negotiate new solutions with the owner, rather than sticking to outdated agreements.

CB9: We are willing to make changes to the contract clauses if necessary.

\section{References}

1. Wang, Y.; Chen, Y.; Fu, Y.; Zhang, W. Do prior interactions breed cooperation in construction projects? The mediating role of contracts. Int. J. Proj. Manag. 2017, 35, 633-646. [CrossRef]

2. Lu, W.; Zhang, L.; Zhang, L. Effect of Contract Completeness on Contractors' Opportunistic Behavior and the Moderating Role of Interdependence. J. Constr. Eng. Manag. 2016, 142, 04016004. [CrossRef]

3. Wu, G.; Zhao, X.; Zuo, J.; Zillante, G. Effects of contractual flexibility on conflict and project success in megaprojects. Int. J. Confl. Manag. 2017, 29, 253-278. [CrossRef]

4. Susarla, A. Contractual flexibility, rent seeking, and renegotiation design: An empirical analysis of information technology outsourcing contracts. Manag. Sci. 2012, 58, 1388-1407. [CrossRef]

5. Zhou, K.Z.; Xu, D. How foreign firms curtail local supplier opportunism in China: Detailed contracts, centralized control, and relational governance. J. Int. Bus. Stud. 2012, 43, 677-692. [CrossRef] 
6. Back, W.E.; Asce, M.; Grau, D.; Mejia-Aguilar, G.; Asce, S.M. Effectiveness evaluation of contract incentives on project performance. Int. J. Constr. Educ. Res. 2013, 9, 1557-8771. [CrossRef]

7. Yaling, D.; Huiling, L.; Peng, Y.; Yilin, Y. Initial Trust, Flexible Contract and Project Management Performance: An Empirical Study on the Intermediary Model. Manag. Rev. 2015, 27, 187-198.

8. Chiara, N.; Kokkaew, N. Risk analysis of contractual flexibility in BOT negotiations: A quantitative approach using risk flexibility theory. Int. J. Eng. Manag. 2009, 1, 71-79.

9. Shan, L.; Garvin, M.J.; Kumar, R. Collar options to manage revenue risks in real toll public-private partnership transportation projects. Constr. Manag. Econ. 2010, 28, 1057-1069. [CrossRef]

10. Chung, W.; Talluri, S.; Narasimhan, R. Quantity flexibility contract in the presence of discount incentive. Decis. Sci. 2014, 45, 49-79. [CrossRef]

11. Levin, J.; Tadelis, S. Contracting for government services: Theory and evidence from U.S. cities. J. Ind. Econ. 2010, 58, 507-541. [CrossRef]

12. Song, H.; Zhu, F.; Klakegg, O.J.; Wang, P. Relationship between contractual flexibility and contractor's cooperative behavior. Int J. Manag. Proj. Bus. 2018, 11, 382-405. [CrossRef]

13. Bachmann, R. Reinhard, Trust, Power and Control in Trans-Organizational Relations. Organ. Stud. 2001, 22, 337-365. [CrossRef]

14. Pei, X.D. Influencing factors of partnership formation in construction industry. Appl. Mech. Mater. 2011, 71-78, 556-559. [CrossRef]

15. Yao, W.; Yilin, Y. The Empirical Study on Impact Relationship between Trust, Risk Allocation and Project Management Performance in Construction Project. Soft Sci. 2014, 28, 101-104.

16. Jap, S.D.; Ganesan, S. Control Mechanisms and the Relationship Life Cycle: Implications for Safeguarding Specific Investments and Developing Commitment. J. Mark. Res. 2000, 37, 227-245. [CrossRef]

17. Jarvinen, M. Trust-building in a coopetitive multi-supplier network. J. Public Procur. 2019, 19, 146-164. [CrossRef]

18. Czernek, K.; Czakon, W.; Marszaek, P. Trust and formal contracts: Complements or substitutes? A study of tourism collaboration in Poland. J. Destin. Mark. Manag. 2017, 6, 318-326. [CrossRef]

19. Wong, S.P.; Cheung, S.O. Trust in construction partnering: Views from parties of the partnering dance. Int. J. Proj. Manag. 2004, 22, 437-446. [CrossRef]

20. Nystén-Haarala, S.; Lee, N.; Lehto, J. Flexibility in contract terms and contracting processes. Int. J. Manag. Proj. Bus. 2010, 3, 462-478. [CrossRef]

21. Kujala, J.; Nystén-Haarala, S.; Nuottila, J. Flexible contracting in project business. Int. J. Manag. Proj. Bus. 2015, 8, 92-106. [CrossRef]

22. Lee, J.N.; Choi, B. Effects of initial and ongoing trust in IT outsourcing: A bilateral perspective. Inf. Manag. 2011, 48, 96-105. [CrossRef]

23. Yaling, D.; Peng, Y. An empirical study about formation mechanism of initial trust in PPP projects. China Civ. Eng. J. 2014, 47, 115-124.

24. Khalfan, M.M.A.; Mcdermott, P.; Swan, W. Building trust in construction projects. Supply Chain Manag. 2007, 12, 385-391. [CrossRef]

25. Hartman, F. The role of trust in project management. In The Frontiers of Project Management Research; Dennis, P.S., David, I.C., Jeffrey, K.P., Eds.; Project Management Institute: Newtown Square, PA, USA, 2002; pp. 225-235.

26. Rousseau, D.M.; Sitkin, S.B.; Burt, R.S.; Camerer, C. Not so different after all: A cross-discipline view of trust. Acad. Manag. Rev. 1998, 23, 393-404. [CrossRef]

27. Lewicki, R.J.; Bunker, B.B. Developing and Maintaining. Trust in Work Relationships; John Wiley \& Sons, Inc.: Hoboken, NJ, USA, 1996; pp. 219-229.

28. Yang, L.; Shuai, C. Dimension analysis of inter-enterprise trust in construction projects. Constr. Econ. 2011, 11, 70-75.

29. Husted, B.W.; Folger, R. Fairness and transaction costs: The contribution of organizational justice theory to an integrative model of economic organization. Organ. Sci. 2004, 15, 719-729. [CrossRef]

30. Liu, Y.; Huang, Y.; Luo, Y.; Zhao, Y. How does justice matter in achieving buyer-supplier relationship performance? J. Oper. Manag. 2012, 30, 355-367. [CrossRef]

31. Huo, B.; Wang, Z.; Tian, Y. The impact of justice on collaborative and opportunistic behaviors in supply chain relationships. Int. J. Prod. Econ. 2016, 177, 12-23. [CrossRef]

32. Ismail, H. Organizational Justice and Citizenship Behavior, the Mediating Role of Trust. Soc. Sci. Electron. Publ. 2017, 5, 86-96. [CrossRef]

33. Quan, Y. Cooperative Behaviors between Partners in Construction Supply Chain and Its Effect on Performance; Chongqing Jiaotong University: Chongqing, China, 2015.

34. Zhang, S.; Zhang, S.; Gao, Y.; Ding, X. Contractual governance: Effects of risk allocation on contractors' cooperative behavior in construction projects. J. Constr. Eng. Manag. 2016, 142, 04016005. [CrossRef]

35. Sujuan, Z.; Yafan, F.; Fei, K. How to foster contractors' cooperative behavior in the Chinese construction industry: Direct and interaction effects of power and contract. Int. J. Proj. Manag. 2018, 36, 940-953.

36. Pearce, R.J. Looking inside the joint venture to help understand the link between inter-parent cooperation and performance. J. Manag. Stud. 2010, 38, 557-582. [CrossRef] 
37. Barthélemy, J.; Quélin, B.V. Complexity of outsourcing contracts and ex post transaction costs: An empirical investigation. J. Manag. Stud. 2010, 43, 1775-1797. [CrossRef]

38. Wang, L.; Yeung, J.H.Y.; Zhang, M. The impact of trust and contract on innovation performance: The moderating role of environmental uncertainty. Int. J. Prod. Econ. 2011, 134, 114-122. [CrossRef]

39. Weber, L.; Mayer, K.J.; Macher, J.T. An analysis of extendibility and early termination provisions: The importance of framing duration safeguards. Acad. Manag. J. 2011, 54, 182-202. [CrossRef]

40. Poppo, L.; Zhou, K.Z. Managing contracts for fairness in buyer-supplier exchanges. Strateg. Manag. J. 2014, 35, 1508-1527. [CrossRef]

41. Huo, B.; Ye, Y.; Zhao, X. The impacts of trust and contracts on opportunism in the 3PL industry: The moderating role of demand uncertainty. Int. J. Prod. Econ. 2015, 170, 160-170. [CrossRef]

42. Faems, D.; Janssens, M.; Madhok, A.; Looy, B.V. Toward an integrative perspective on alliance governance: Connecting contract design, trust dynamics, and contract application. Acad. Manag. J. 2008, 51, 1053-1078. [CrossRef]

43. Poppo, L.; Zenger, T. Do formal contracts and relational governance function as substitutes or complements? Strateg. Manag. J. 2002, 23, 707-725. [CrossRef]

44. Pei, Z. Research on Impact of Employer's and Contractor's Trust on Cooperation in Construction Project: From a Perspective of Contractural Flexibiltiy. Ph.D. Thesis, Tianjin University, Tianjin, China, 2014.

45. Chow, P.T.; Cheung, S.O.; Chan, K.Y. Trust building in construction contracting. Int. J. Proj. Manag. 2012, 30, 927-937. [CrossRef]

46. Manu, E.; Ankrah, N.; Chinyio, E.; Proverbs, D. Trust influencing factors in main contractor and subcontractor relationships during projects. Int. J. Proj. Manag. 2015, 33, 1495-1508. [CrossRef]

47. Dyer, J.H.; Chu, W. The determinants of trust in supplier-automaker relationships in the U.S. Japan and Korea. J. Int. Bus. Stud. 2011, 42, 10-27. [CrossRef]

48. Schoenherr, T.; Narayanan, S.; Narasimhan, R. Trust formation in outsourcing relationships: A social exchange theoretic perspective. Int. J. Prod. Econ. 2015, 169, 401-412. [CrossRef]

49. Goo, J.; Kishore, R.; Rao, H.R.; Nam, K. The role of service level agreements in relational management of information technology outsourcing: An empirical study. MIS Q. 2009, 33, 119-145. [CrossRef]

50. Rezvani, A.; Chang, A.; Wiewiora, A.; Ashkanasy, N.M.; Jordan, P.J.; Zolin, R. Manager emotional intelligence and project success: The mediating role of job satisfaction and trust. Int. J. Proj. Manag. 2016, 34, 1112-1122. [CrossRef]

51. Zhang, S.B.; Chen, J.Y.; Hu, Z.Y. Effect of contract on contractor's cooperative behavior in construction project: Trust as a mediator. J. Eng. Manag. 2015, 4, 6-11.

52. Turner, J.R. Farsighted project contract management: Incomplete in its entirety. Constr. Manag. Econ. 2004, 22, 75-83. [CrossRef]

53. Cruz, C.O.; Rui, C.M. Flexible contracts to cope with uncertainty in public-private partnerships. Int. J. Proj. Manag. 2013, 31, 473-483. [CrossRef]

54. Huber, T.L.; Fischer, T.A.; Dibbern, J.; Hirschheim, R. A process model of complementarity and substitution of contractual and relational governance in IS outsourcing. J. Manag. Inf. Syst. 2013, 30, 81-114. [CrossRef]

55. Cai, W.; Abdel-Malek, L.; Hoseini, B.; Dehkordi, S.R. Impact of flexible contracts on the performance of both retailer and supplier. Int. J. Prod. Econ. 2015, 170 Pt B, 429-444. [CrossRef]

56. Griffith, D.A.; Harvey, M.G.; Lusch, R.F. Social exchange in supply chain relationships: The resulting benefits of procedural and distributive justice. J. Oper. Manag. 2006, 24, 85-98. [CrossRef]

57. Schalk, R.; Petru, L.; Curseu, D.; Zhang, Z.; Jia, M. Procedural fairness and cooperation in public-private partnerships in China. J. Manag. Psychol. 2010, 25, 513-538.

58. Luo, Y. Procedural fairness and interfirm cooperation in strategic alliances. Strateg. Manag. J. 2008, 29, 27-46. [CrossRef]

59. Anvuur, A.M.; Kumaraswamy, M.M. Measurement and antecedents of cooperation in construction. J. Constr. Eng. Manag. 2012, 138, 797-810. [CrossRef]

60. Wong, Y. Job security and justice: Predicting employees' trust in Chinese international joint ventures. Int. J. Hum. Resour. Manag. 2012, 23, 4129-4144. [CrossRef]

61. Wu, Z.; Chen, Y. Relationship Fairness, Interfirm Trust and Cooperative Performance: An Empirical Study on China's Enterprises. Sci. Sci. Manag. S. T 2010, 31, 143-149.

62. Nitzl, C. Partial Least Squares Structural Equation Modelling (PLS-SEM) in Management Accounting Research: Directions for Future Theory Development. J. Account. Lit. 2016, 37, 19-35. [CrossRef]

63. Du, Y.L.; Li, H.L.; Ke, H. An empircal study on initial trust of the owner to cooperation: The intermediary role of perceived justice of the contractor. Chin. J. Manag. 2014, 11, 1542-1551.

64. Colquitt, J.A.; Conlon, D.E.; Wesson, M.J.; Porter, C.O.; Ng, K.Y. Justice at the millennium: A meta-analytic review of 25 years of organizational justice research. J. Appl. Psychol. 2001, 86, 425-445. [CrossRef]

65. Jia, F.Q.; Bennett, M.M. Chinese infrastructure diplomacy in Russia: The geopolitics of project type, location, and scale. Eurasian Geogr. Econ. 2018, 59, 340-377. [CrossRef]

66. Theis, S.; Ruppert, J.L.W.; Roberts, K.N.; Minns, C.K.; Koops, M.; Poesch, M.S. Compliance with and ecosystem function of biodiversity offsets in North American and European freshwaters. Conserv. Biol. 2020, 34, 41-53. [CrossRef] [PubMed]

67. Zollo, M.; Reuer, J.J.; Singh, H. Interorganizational routines and performance in strategic alliances. Organ. Sci. 2002, 13, 701-713. [CrossRef] 
68. MacKenzie, S.B.; Podsakoff, P.M. Common method bias in marketing: Causes, mechanisms, and procedural remedies. J. Retail. 2012, 88, 542-555. [CrossRef]

69. Hair, J.F.; Black, W.C.; Babin, B.J.; Anderson, R.E.; Tatham, R.L. Multivariate data analysis. Technometrics 2012, 15, 648-650.

70. Bagozzi, R.P.; Yi, Y. On the Evaluation of Structure Equation Models. J. Acad. Mark. Sci. 1988, 16, 74-94. [CrossRef]

71. Fornell, C.; Larcker, D.F. Evaluating Structural Equation Models with Unobservable Variables and Measurement Error. J. Mark. Res. 1981, 18, 39-50. [CrossRef]

72. Chen, R.; Zheng, Y.; Liu, M.W. Mediation Analysis: Principles, Procedures, Bootstrap Methods and Applications. J. Mark. Sci. 2013, 9, 120-135.

73. Harris, A.; Giunipero, L.C.; Hult, G.T.M. Impact of organizational and contract flexibility on outsourcing contracts. Ind. Mark. Manag. 1998, 27, 373-384. [CrossRef]

74. Bartling, B.; Schmidt, K.M. Reference points, cosial norms, and fairness in contract renegotiations. J. Eur. Econ. Assoc. 2015, 13, 98-129. [CrossRef] 